\title{
Observation on cattle liveweight changes and fecal indices in Sudan
}

IBRAHIM M. HASHIM AND BABO FADLALLA

\section{Abstract}

Changes in liveweight of sedentary and migratory herds of cattle in south Kordofan Province, Sudan, were determined monthly. Feces of these animals were analyzed for $\mathbf{N}$ and $\mathbf{A D F}$ during the same period. Both the sedentary and the migratory herds gained liveweights during periods Auguat to September and November to February and lost liveweight during October and from March to July. Changes in liveweights were more highly related to feeal ADF concentrations $(r=-0.60, P<0.002)$ than to fecal $N$ concentrations $(r=-0.085, P<0.305)$.

Key Words: cattle, sedentary, migratory, liveweights, fecal constituents

Sedentary operations and transhumance are the 2 systems involved in liveweight production in many parts of the Sudan. These 2 systems are mainly practiced in the western provinces, including Kordofan and Dar Fur. In Kordofan transhumants migrate to the arid, sandier ranges of the north during the rainy season and return to specific locations in the clay-dominated ranges of the south in the Nuba Mountains during the dry season. The sedentary operators, on the other hand, remain in the claydominated ranges of the Nuba Mountains throughout the year, although they make local movements about these ranges.

Because the Nuba Mountain ranges are utilized by many sedentary and migratory livestock, it is important to know the quality of these ranges. One approach to determine this is through ohemical analysis of feces voided by free-ranging ruminants.

High relationships between dietary $\mathbf{N}$ and fecal $\mathbf{N}$ have been reported by Raymond (1949), Hinnant (1979), Mould and Robbins (1981), Holechek et al. (1982), Bredon et al. (1983), and Mubanga (1983). These relationships resulted in the hypothesis that liveweights of cattle could be predicted from the $\mathrm{N}$ contents of their feces. The objective of the present study was to determine liveweight changes and chemical constituents of feces, including $\mathbf{N}$ and ADF, of the sedentary and the migratory herds in south Kordofan, Sudan.

\section{Study Area}

This study was conducted at Kadugli Research Station in south Kordofan. South Kordofan lies within the savanna zone of the Sahelian belt, and can be classified as having a hot, semiarid climate. March is the hottest month at Kadugli with a maximum of $41^{\circ} \mathrm{C}$ and a minimum of $24^{\circ} \mathrm{C}$. December and January are the coolest months with a maximum of $35^{\circ} \mathrm{C}$ and a minimum of $18^{\circ} \mathrm{C}$. Rainfall varies from about $500 \mathrm{~mm}$ in the north to over $800 \mathrm{~mm}$ in the south. Rains occur in a single season (Khareef), primarily from June to September, although some rains also fall in May and October. A short, hot season (Deret) occurs after the rains from October to November, followed by cool, dry season (Shitta) from December to February. The main hot season (Saif) occurs from March to early June.

Bunderson et al. (1984) identified soil types in rangelands of south Kordofan. These soils included gravely grey soils: red, loamy

\footnotetext{
Authors are range scientist and animal nutritionist, respectively, WSARP, P.O Box 125, Khartoum North, Sudan.

The authors wish to thank Dr. M. Galyean, Dr. R.D. Pieper, and Dr. J.L. Holechek for their belpful criticism of the manuscript.

Manuscript accepted 22 September 1988.
}

soils; dark, heavy cracking clays; brown, coarse loamy clays; sandy clay and loams; very dark cracking clays; red noncracking clays; dark, medium cracking clays; redish-white loamy sands; brown noncracking clays.

Range productivities vary according to soil types, being highest in the very dark, heavy cracking clays and lowest in the brown, coarse sandy loams.

\section{Methods}

Two herds of cattle were bought by the Western Sudan Agricultural Research Project (WSARP) at Kadugli Research Station. One herd of 80 cattle was kept in the fenced research farm (760.62 ha), where the dominant soils were dark cracking clays. This herd was stocked at $9 \mathrm{ha} / \mathrm{head} /$ year to simulate the sedentary system. The other herd of the same size was allowed to migrate with the transhumants to simulate their system.

Liveweights of 10 bulls selected randomly from each of the sedentary and the transhumant systems were determined monthly from November 1984 to November 1985. Cows were excluded from this selection to avoid changes in liveweights that might accrue from pregnancy, calving, or lactation rather than the nutritional value of the range forage.

Liveweights were determined monthly by confining the bulls overnight without food and water before weighing. Changes in livesweight per bull were calculated by subtracting the total starting monthly, weight from the total ending monthly weight and dividing this difference in liveweight: by the number of bulls in each herd.

Ten grab samples of feces were collected every 2 weeks from the selected bulls in the 2 herds for laboratory analysis. These samples were oven-dried at $50^{\circ} \mathrm{C}$, pooled and analyzed chemically for $\mathrm{N}$ and ADF. Nitrogen was determined by the standard Kjeldahl $\mathbf{N}$ procedure. Acid-detergent fiber was determined according to the method described by Van Soest (1982). Monthly averages of fecal $A D F$ and $\mathrm{N}$ for each herd were related to the monthly change in

Table 1. Liveweifht changes and chemical constituents of feces of sedentary and migratory cattle in south Kordofan, Sudan.

\begin{tabular}{|c|c|c|c|c|c|c|}
\hline \multirow[b]{2}{*}{ Month } & \multicolumn{3}{|c|}{ Sedentary cattle } & \multicolumn{3}{|c|}{ Migratory cattle } \\
\hline & $\begin{array}{c}\text { Wt. } \\
\text { change/ } \\
\text { bull, kg }\end{array}$ & $\begin{array}{c}\% \\
\text { fecal } \\
\mathbf{N}\end{array}$ & $\begin{array}{c}\% \\
\text { fecal } \\
\text { ADF }\end{array}$ & $\begin{array}{l}\text { Wt. } \\
\text { change/ } \\
\text { bull, kg }\end{array}$ & $\begin{array}{c}\% \\
\text { fecal } \\
N\end{array}$ & $\begin{array}{c}\% \\
\text { fecal } \\
\text { ADF }\end{array}$ \\
\hline November 84 & -4.61 & 1.64 & 57.95 & 5.85 & 1.45 & 53.98 \\
\hline December 84 & -0.23 & 1.27 & 50.48 & 9.30 & 1.46 & 51.84 \\
\hline January 85 & 1.64 & 1.52 & 50.32 & 18.39 & 1.61 & 52.70 \\
\hline February 85 & 13.69 & 1.21 & 52.75 & 26.43 & 1.19 & 56.11 \\
\hline March 85 & 0.31 & 1.12 & 57.53 & -4.56 & 1.15 & 59.43 \\
\hline April 85 & -2.68 & 1.06 & 60.35 & -6.24 & 0.99 & 60.18 \\
\hline May 85 & -1.36 & 1.09 & 60.62 & -19.04 & 1.09 & 60.68 \\
\hline June 85 & -21.57 & 1.78 & 67.44 & -40.61 & 1.46 & 63.04 \\
\hline July 85 & -16.43 & 2.04 & 64.22 & -13.38 & 1.50 & 63.83 \\
\hline August 85 & 29.86 & 1.85 & 55.49 & 0.12 & 1.47 & 54.91 \\
\hline September 85 & 20.78 & 1.56 & 57.83 & 43.43 & 1.21 & 56.17 \\
\hline October 85 & -12.08 & 1.54 & 57.77 & -10.91 & 1.53 & 58.43 \\
\hline
\end{tabular}


Wt change $=143.7-2.48$ ADF

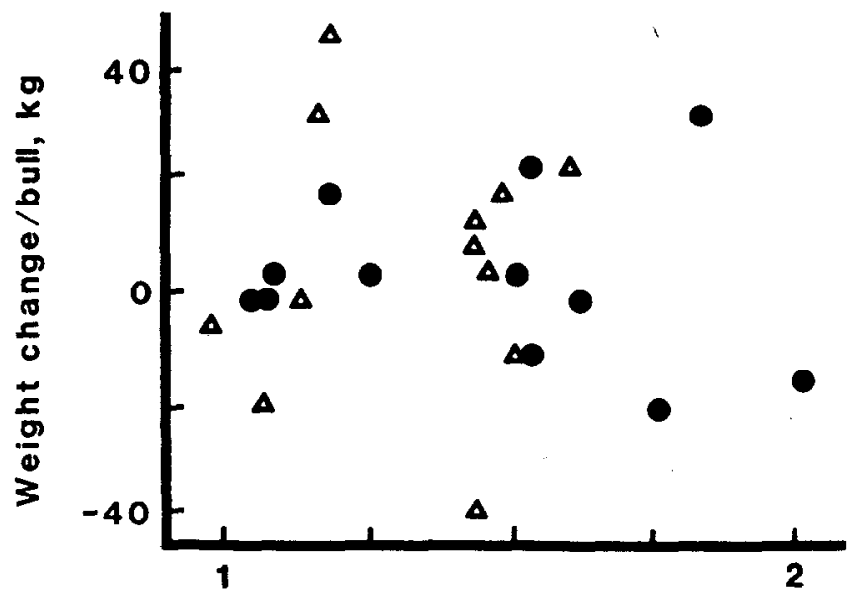

\% Fecal $\mathbf{N}$

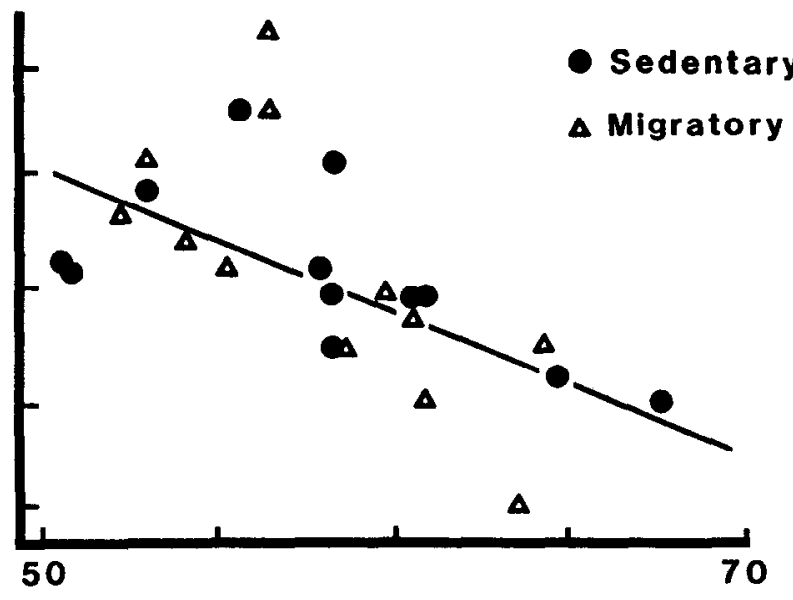

\% Fecal ADF

Fig. 1. Relationships between liveweight change and fecal $N$ or ADF of sedentary and migratory cattle in south Kordofan, Sudan.

liveweight per bull by multiple regression analysis (Draper and Smith 1966).

\section{Results and Discussion}

Seasonal changes in liveweight and chemical constituents of feces of the sedentary and the migratory herds are presented in Table 1. Liveweights changed during 4 seasons. The first and the longest season in which a decrease in liveweight occurred extended from March to July (Saif). Quantity and quality of range forage became limiting during the dry season. Bunderson et al. (1984) reported that diet selected by cattle during this season contained $5.9 \%$ crude protein; intake of dry matter, digestible dry matter, and crude protein were $4,472,2,665$, and $264 \mathrm{~g} \mathrm{~g} /$ head/day, respectively. Intake of crude protein barely met the maintenance requirements of cattle during Saif.

The second decrease in liveweight occurred in October. This decrease continued in November and December for the sedentary but not for the migratory cattle. The reason for this decrease is not clear as forage was abundant for the $\mathbf{2}$ herds in October. However, rainfall patterns differed in the 2 areas grazed by sedentary and migratory cattle during 1984 and 1985.

The 2 herds showed an increase in liveweights in 2 seasons. The first season was in late Khareef, August and September, when the 2 herds recorded maximum gains in liveweight. The second season (Shitta) extended roughly from November until February. Diet selected by cattle during the Khareef and Shitta contained $11.7 \%$ and $8.2 \%$ crude protein, respectively; intake of dry matter, digestible dry matter and crude protein during the same seasons were $5,311,3,468$, and $621 \mathrm{~g} / \mathrm{head} / \mathrm{day}$ for the Khareef and 6,318, 3,576 and $518 \mathrm{~g} / \mathrm{head} /$ day for Shitta, respectively (Bunderson et al. 1984).

During the Khareef and Shitta the migratory herd gained slightly more liveweight than the sedentary herd. Gains by the 2 herds in these 2 seasons were offset by losses in Deret and Saif so yearly average change in liveweights were similar, suggesting that neither of the systems performed better than the other.

Two problems are involved in using change in liveweight to describe condition of free-ranging cattle (Lloyd et al. 1978). First there is no established normal liveweight from which variations may be allowed. Second, liveweight is not always an index of health because overweight animals may be undernourished while underweight animals may be well nourished. However, liveweight change may be a good index of health. In addition, liveweights could be affected by factors irrelevant to the nutritive value of range forage, such as reproductive stage, long distance movements, and parasites.

The relationships between liveweight change and fecal $\mathrm{N}$ or fecal ADF are presented in Figure 1. Relationships between liveweight changes and chemical constituents of feces were based on findings by previous investigators that weight gain (Holechek et al. 1982) and liveweight change (Squires and Siebert 1983) were significantly related to fecal $\mathrm{N}$, and that fecal $\mathrm{N}$ and dietary $\mathrm{N}$ were highly correlated. However, fecal ADF was more highly related to liveweight change $(r=-0.60, P<0.002)$ than was fecal $\mathrm{N}(r=-0.085$, not significant). The inverse relationship between liveweight change and fecal ADF could indicate that energy, not protein, appeared to control gain in liveweight. Van Soest (1982) reported that ADF was inversely related to digestible energy and intake of forages.

Our finding is in contrast to the work of Squires and Siebert (1983), who found that fecal $\mathrm{N}$ was significantly and directly related to changes in liveweight of cattle. Van Soest (1982) questioned the relationship between fecal $\mathrm{N}$ and dietary $\mathrm{N}$ because there was no evidence of potentially digestible feed protein in feces. He argued that protein in feces was quantitatively insoluble and was either keratin, Millard products (nitrogen rendered indigestible through heating of forages), or bound $\mathrm{N}$ and therefore resistant to peptic digestion. Therefore fecal $\mathbf{N}$ had no relationship to digestible dietary $\mathbf{N}$.

\section{Literature Cited}

Bredon, R.M., K.W. Harker, and B. Marshall. 1963. The nutritive value of grasses grown in Uganda when fed to Zebu cattle. 1. The Relationship between the \% CP and the nutrients. J. Agr. Sci. 16:101-104.

Bunderson, W.T., R.H. Cook, and B. Fadlalla. 1984. Range/livestock research activities 1982/1983. WSARP publication No. 29. Khartoum, Sudan and Pullman, Washington, USA.

Draper, N.R., and H. Smith. 1966. Applied regression analysis. John Wiley and Sons, New York.

Hinnant, R.T. 1979. Blood, rumen liquor, and fecal components as affected by dietary crude protein. M.S. Thesis. Texas A M Univ. College Station.

Holechek, J.L., M. Vavra, and D. Arthun. 1982. Relationship between performance, intake, diet nutritive quality of cattle and fecal nutritive quality of cattle on mountain range. J. Range Manage. 36:741-744.

Lloyd, L.E., B.E. MeDonald, and E.W. Crampton. 1978. Fundamental of nutrition. Second edition. W.H. Freeman \& Co. San Francisco. 
Mould, E.D., and C.T. Robblns. 1981. Nitrogen metabolism in elk. J. Wild. Manage. 45:323-334.

Mubanga, G. 1983. Use of fecal indices to predict forage quality and intake of mule deer. M.S. Thesis. New Mexico State Univ., Las Cruces.

Raymond, W.F. 1948. Evaluation of herbage for grazing. Nature 161:937-945.
Squires, V.R., and B.D. Siebert. 1983. Botanical and chemical components of the diet and liveweight change in cattle on semi-desert rangeland in central Australia. Australian Rangeland J. 5:28-34.

Van Soent, P.J. 1982. Nutritional ecology of the ruminants. O \& B Books Inc. Corvallis, Oregon. 